\title{
P-cadherin Inhibitor PCA062
}

National Cancer Institute

\section{Source}

National Cancer Institute. P-cadherin Inhibitor PCA062. NCI Thesaurus. Code C121216.

An agent that inhibits p-cadherin, with potential antineoplastic activity. Upon intravenous infusion, PCA062 binds to and inhibits the activity of p-cadherin. Inhibition of the activity of $p$-cadherin may inhibit both invasion and proliferation of $\mathrm{p}$-cadherin expressing tumor cells. P-cadherin, a cell-surface protein and member of the cadherin family, is overexpressed in a variety of tumors and plays a role in cell adhesion, motility, invasion, and proliferation. 